\section{'Carolina Gold', a Hybrid Tomato, and Its Parents, NC 1Y and NC 2Y}

\section{R.G. Gardner ${ }^{1}$ \\ Department of Horticultural Science, North Carolina State University, Raleigh, NC 27695-7609}

Additional index words. Lycopersicon esculentum, vegetable breeding, fruit quality, disease resistance

'Carolina Gold' is an orange-fruited $(t$ gene), $\mathrm{F}_{1}$ hybrid tomato with a desirable combination of plant, fruit, and disease resistance

Received for publication 7 July 1999. Accepted for publication 5 Nov. 1999. The use of trade names in this publication does not imply endorsement by the North Carolina Agricultural Research Service (NCARS) of the products named, nor criticism of similar ones not mentioned. This research was funded by the NCARS and the North Carolina Tomato Growers Association. The cost of publishing this paper was defrayed in part by the payment of page charges. Under postal regulations, this paper therefore must be hereby marked advertisement solely to indicate this fact.

${ }^{1}$ E-mail address: Randy_Gardner@ncsu.edu characteristics. 'Carolina Gold' is earlier in maturity than 'Mountain Gold' PVP(Gardner, 1993) and has much better resistance to the fruit-ripening disorder graywall than does 'Mountain Gold'.

\section{Origin}

'Carolina Gold' is the $\mathrm{F}_{1}$ hybrid of NC $1 \mathrm{Y}$ $x$ NC2 $Y$, inbred lines in the $\mathrm{F}_{6}$ generation (Fig. 1). NC 1Y resulted from the cross of 'Mountain Gold' PVP with the line NC 82162(X)-1$1 \mathrm{R}-8$, which sets fruit at high temperature. NC $2 \mathrm{Y}$ resulted from crosses of sister lines of the NC 822 orange-fruited $(t)$ family with the
Univ. of Florida red-fruited releases 'Suncoast' and FLA 7060 PVP. Orange-fruited segregants from $\mathrm{F}_{2}$ populations of these two crosses were crossed, selfed, and selected to produce NC 2Y (Fig. 1). 'Carolina Gold' was tested as NC 9267.

\section{Description}

NC $1 Y$. Plant habit is determinate $(s p)$ (Mutschler et al., 1987), with noncurled foliage that provides good coverage for fruit protection against weather-related defects. Fruit of NC $1 Y$ are deep oblate to flattened globular. Immature fruit are uniform green $(u)$. Fruit pedicels are jointed. Fruit ripen to a uniform yellowish-orange exterior and interior color. Fruit are firm and similar in flavor to 'Mountain Gold' (subjective ratings by author). NC $1 Y$ yielded more than 'Mountain Gold' in early- and total-season harvests over 4 years in seven replicated trials. U.S. combination grade yield (U.S. No. $1+$ U.S. No. 2) and fruit size did not differ significantly from that of 'Mountain Gold' when averaged over all trials (Table $1)$.

$\mathrm{NC} 1 \mathrm{Y}$ is resistant ( $I$ and $I-2$ genes) to races 1 and 2 of Fusarium oxysporum f.sp. lycopersici (Sacc.) Snyd. and Hans., the incitant of fusarium wilt, and is resistant ( $V e$ gene) to race

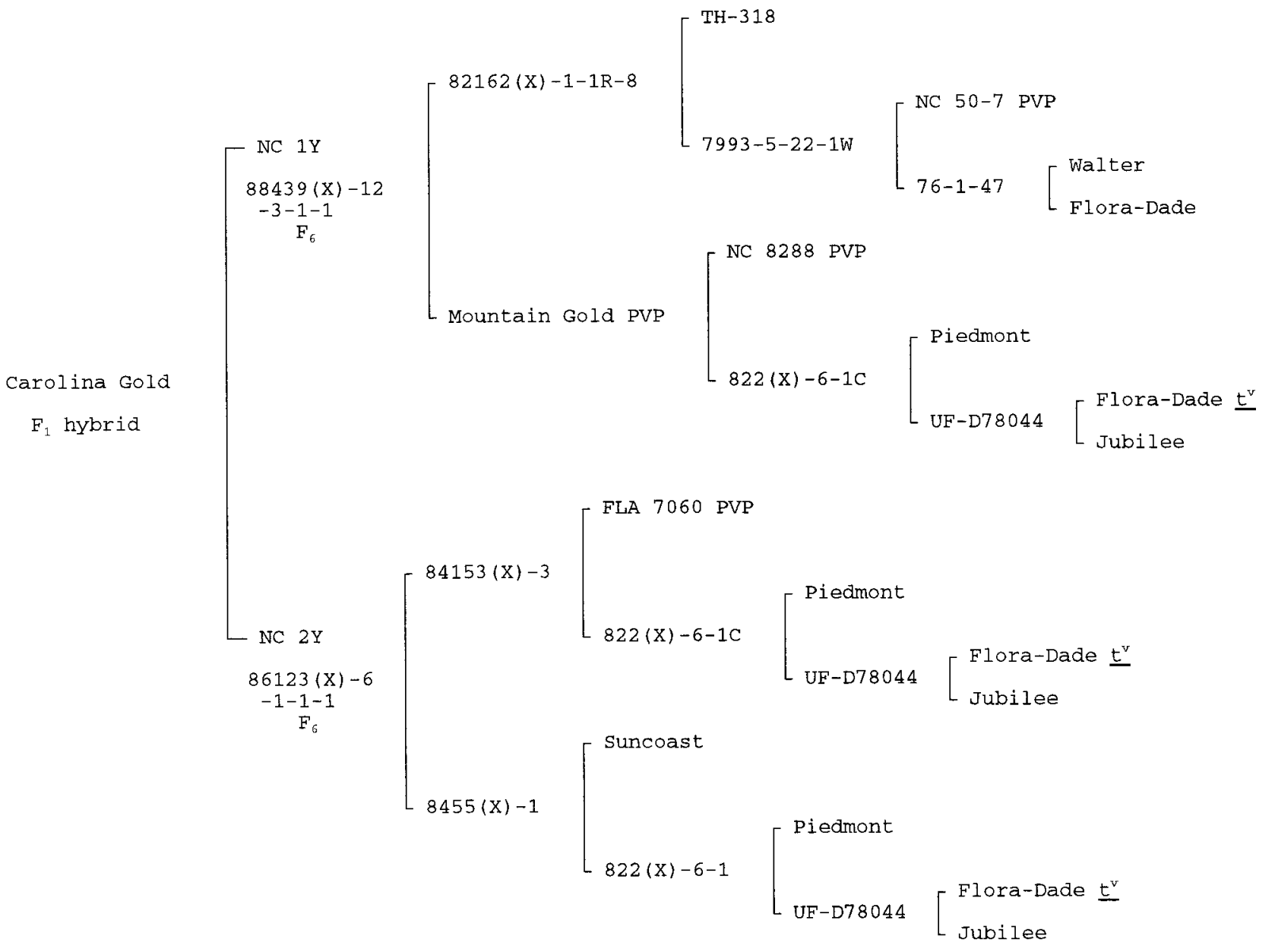

Fig. 1. Pedigrees of 'Carolina Gold' $F_{1}$ hybrid tomato and its parental lines. 
Table 1. Comparison of yields and fruit weight of 'Carolina Gold' tomato hybrid with those of its parental lines, NC 1Y and NC 2Y, and of 'Mountain Gold' PVP in staked, vine-ripe harvest trials at Fletcher, N.C. ${ }^{\mathrm{z}}$

\begin{tabular}{|c|c|c|c|c|}
\hline \multirow{4}{*}{$\begin{array}{l}\text { Cultivar } \\
\text { or line }\end{array}$} & \multicolumn{3}{|c|}{ Yield $\left(\mathrm{Mg} \mathrm{ha}^{-1}\right)$} & \multirow[b]{3}{*}{ Wt/fruit } \\
\hline & \multirow[b]{2}{*}{$\underline{\text { Early season }}^{y}$} & \multicolumn{2}{|c|}{ Total season } & \\
\hline & & & U.S. combination & \\
\hline & Nongraded & Nongraded & $\operatorname{grade}^{\mathrm{x}}$ & (g) \\
\hline Carolina Gold & 27 & 110 & 62 & 339 \\
\hline Mountain Gold PVP & 19 & 94 & 49 & 316 \\
\hline NC $1 Y$ & 28 & 106 & 58 & 302 \\
\hline $\mathrm{NC} 2 \mathrm{Y}$ & 15 & 88 & 35 & 372 \\
\hline $\mathrm{LSD}_{0.05}$ & 5 & 10 & 9 & 20 \\
\hline
\end{tabular}

${ }^{\mathrm{z}}$ Based on seven replicated trials conducted over a 4-year period (1993-96).

${ }^{y}$ First 2 weeks of harvest.

${ }^{x}$ U.S. No. 1 + U.S. No. 2 fruit.

1 of Verticillium dahliae Kleb., the incitant of verticillium wilt. Fruit are highly resistant to the physiological fruit-ripening disorder graywall. Fruit are also resistant to radial and concentric cracking and cuticle cracking (weather check).

$N C 2 Y$. Plant habit is determinate $(s p)$ with moderate foliage cover. $\mathrm{NC} 2 \mathrm{Y}$ produces very large fruit (Table 1) that are round to slightly ovate. Immature fruit are uniform light green (u). Fruit ripen to a bright yellowish-orange exterior and interior color and have a firm texture. Fruit pedicels are jointed.

$\mathrm{NC} 2 \mathrm{Y}$ is resistant to fusarium wilt ( $I$ and $I$ 2) and verticillium wilt ( $V e)$, and fruit are highly resistant to graywall. Fruit are moderately susceptible to radial and cuticle cracking, resulting in a lower percentage of fruit in U.S. combination grade (U.S. No. $1+$ U.S. No. 2) than other orange tomatoes tested. Total and U.S. combination grade fruit yields averaged lower than other orange tomatoes evaluated. Early yield was lower than that of "Carolina Gold' and NC 1Y but not significantly lower than that of 'Mountain Gold' when averaged over seven trials (Table 1).

'Carolina Gold'. Vine type of 'Carolina Gold' is similar to that of 'Mountain Gold'. The plant is determinate $(s p)$ with good foliage cover for fruit protection and is well adapted to the short-stake, string-weave system of culture. Fruit of 'Carolina Gold' are deep oblate to flattened globular and are well-filled and symmetrical. The blossom scar is generally small and smooth. Immature fruit are uniform glossy green $(u)$. Fruit ripen to a uniform bright yellowish-orange exterior and interior color. Ripe fruit are firm with good shelf-life and are comparable in flavor to those of 'Mountain Gold'(subjective ratings by author). Fruit pedicels are jointed. 'Carolina Gold' averaged higher than 'Mountain Gold' in early, total, and U.S. combination grade (U.S. No. $1+$ U.S. No. 2) yields in seven replicated trials conducted over a 4-year period. Average fruit weight was equal to or greater than that of 'Mountain Gold' in all trials (Table 1).

'Carolina Gold' is resistant to fusarium wilt ( $I$ and $I-2)$ and verticillium wilt (Ve), as well as fruit cracking and weather check, and is highly resistant to graywall. No graywall was observed in fruit of 'Carolina Gold' or either of its parents in trials at Fletcher, N.C., in 1994 and 1996, whereas the incidence of graywall was $25 \%$ to $44 \%$ in 'Mountain Gold'.

\section{Use}

'Carolina Gold' will provide growers with improvements in earliness, fruit quality, and yield over 'Mountain Gold'. Although orange tomatoes are produced on a limited basis as a specialty item, their market share is increasing, and growers usually receive a premium for orange tomatoes.

$\mathrm{NC} 1 \mathrm{Y}$ and NC $2 \mathrm{Y}$ are not intended for direct use as cultivars. Their fruit quality and disease resistance, in combination with the $t$ gene, should make them useful to other breeders in further breeding of orange-fruited cultivars.

\section{Availability}

'Carolina Gold' was released on an exclusive basis for commercial seed production and sales to Novartis Seeds, Inc. Applications for Plant Variety Protection Certificates have been filed for NC 1Y and NC 2Y. Small samples of 'Carolina Gold', NC 1Y, and NC 2Y for trial and breeding purposes are available from R.G. Gardner, Mountain Horticultural Crops Research and Extension Center, Fletcher, N.C. 28732-9244.

\section{Literature Cited}

Gardner, R.G. 1993. 'Mountain Gold' tomato. HortScience 28:348-349.

Mutschler, M.A., S.D. Tanksley, and C.M. Rick. 1987 linkage maps of the tomato (Lycopersicon esculentum). Rpt. Tomato Genet. Coop. 37:534. 